\title{
NATURA 2000 JAKO DZIAŁANIE NA RZECZ ZRÓWNOWAŻONEGO ROZWOJU
}

Szeroko rozumiany zrównoważony rozwój jest ostatnio przedmiotem dociekań wielu naukowców zajmujących się prawem ochrony środowiska. Definicja legalna owego pojęcia została zamieszczona w ustawie z dnia 27 kwietnia 2001 r. Prawo ochrony środowiska. ${ }^{1}$ Przez zrównoważony rozwój należy rozumieć taki rozwój społeczno-gospodarczy, w którym następuje proces integrowania działań politycznych, gospodarczych i społecznych, z zachowaniem równowagi przyrodniczej oraz trwałości podstawowych procesów przyrodniczych, w celu zagwarantowania możliwości zaspokajania podstawowych potrzeb poszczególnych społeczności lub obywateli zarówno współczesnego pokolenia, jak i przyszłych pokoleń (art. 3 pkt 50 p.o.ś.). Jak zauważył K. Gruszecki w komentarzu do ustawy prawo ochrony środowiska, znaczenie ustawowych definicji zawartych w art. 3 p.o.ś. znacząco wykracza poza jej ramy i ma bardzo duże znaczenie praktyczne. ${ }^{2}$ Zdaniem B. Rakoczego, zrównoważony rozwój nie powinien być definiowany, lecz powinien stanowić klauzulę generalną, ponieważ koncepcja zrównoważonego rozwoju jest na tyle obszerna i bogata, że ujęcie definicyjne pozbawia jej tych atrybutów. Co więcej, Autor twierdzi, iż umieszczenie definicji zrównoważonego rozwoju w ustawie prawo ochrony środowiska ogranicza tę definicję jedynie do problemów ochrony środowiska. B. Rakoczy nazywa zasadę zrównoważonego rozwoju „złotym środkiem” w rozwiązaniu konfliktu pomiędzy różnymi wartościami, przy czym jedną z nich jest właśnie ochrona środowiska. ${ }^{3}$ Środowisko jest przykładem dóbr publicznych. Zatem należy zaznaczyć, że z założenia dobra publiczne mają charakter nieodpłatny, nikogo nie można wykluczyć z korzystania z tego dobra i przysługują każdemu. W związku z tym, dobro to powinno być otoczone ochroną w taki sposób, aby mogło służyć współczesnej, jak i przyszłej ludzkości. Przykładem formy ochrony przyrody gwarantują-

\footnotetext{
Dz.U. z 2014 r. poz. 1322, t.j., dalej jako: „p.o.ś.”.

K. Gruszecki, Prawo ochrony środowiska. Komentarz, wydanie III, Stan prawny na 1.06.2011 r., dostęp: Lex.

J. Ciechanowicz-McLean, Z. Bukowski, B Rakoczy, Prawo ochrony środowiska. Komentarz, Warszawa 2008, s. 48.
} 
cej racjonalną gospodarkę przyrodniczą (w tym jej ochronę) jest sieć Natura 2000, na terenie której możliwy jest zrównoważony rozwój. Natura 2000 jako działanie na rzecz zrównoważonego rozwoju przejawia się przede wszystkim przez tworzenie regulacji prawnych. W prawie międzynarodowym podaje się, że konwencja z Ram$\operatorname{sar}^{4}$ z 1971 r., konwencja bońska ${ }^{5}$ i berneńska ${ }^{6}$ z 1979 r. oraz konwencja o różnorodności biologicznej z Rio de Janeiro ${ }^{7}$ z 1992 r. przyczyniły się do ochrony zasobów przyrodniczych. W prawie europejskim z kolei są to dyrektywa ptasia ${ }^{8}$ i dyrektywa siedliskowa, ${ }^{9}$ które stały się fundamentem utworzenia sieci Natura 2000.

Niniejsze opracowanie ma na celu przybliżenie zarysu problematyki funkcjonowania obszarów Natura 2000 oraz ich związku z zasadą zrównoważonego rozwoju. Kluczowe będzie wskazanie jej istoty oraz zbadanie, czy możliwe jest dokonywanie inwestycji na obszarach objętych właśnie tą formą ochrony przyrody.

Środowisko przyrodnicze Europy, jak również całego świata ulega ciągłym zmianom wynikającym z rozwoju cywilizacyjnego. W związku z tym równowaga przyrodnicza jest zachwiana, co skutkuje m.in. zmniejszaniem się różnorodności biologicznej, zanikaniem poszczególnych gatunków. Zagrożenia płynące z rozwoju cywilizacji spowodowały tworzenie się idei prawnej ochrony przyrody i jej zasobów. Działania te w poszczególnych krajach postępowały w zróżnicowanym tempie. Nie ma wątpliwości, że przynależność do organizacji międzynarodowych czy ugrupowań o charakterze integracyjnym ułatwiają podjęcie i koordynację działań na rzecz rozwoju spójnej ochrony przyrody. W przypadku Europy impulsem do rozwoju spójnej polityki ochrony dziedzictwa przyrodniczego jest proces integracji europejskiej, w ramach którego stworzono sieć Natura 2000. W doktrynie wyróżnia się podział obszarów Natura 2000 na aspekt europejski oraz aspekt polski.

\section{Aspekt prawny Natury 2000 w świetle prawa unijnego}

Kluczowym wyzwaniem współczesnego świata jest ochrona środowiska rozumiana sensu largo polegająca m.in. na zrównoważonym wykorzystywaniu zasobów środowiska, sprawiedliwym podziale korzyści czerpanych z zasobów genetycznych

\footnotetext{
$4 \quad$ Konwencja o obszarach wodno-błotnych mających znaczenie międzynarodowe, zwłaszcza jako środowisko życiowe ptactwa wodnego, sporządzona w Ramsarze dnia 2 lutego 1971 r., Dz.U. z 1978 r. Nr 7, poz. 24.

5 Konwencja o ochronie wędrownych gatunków dzikich zwierząt, sporządzona w Bonn dnia 23 czerwca 1979 r., Dz.U. z 2003 r. Nr 2, poz. 17.

$6 \quad$ Konwencja o ochronie gatunków dzikiej flory i fauny europejskiej oraz ich siedlisk, sporządzona w Bernie 19 września 1979 r., Dz.U. z 1996 r. Nr 58, poz. 263.

$7 \quad$ Konwencja o różnorodności biologicznej, sporządzona w Rio de Janeiro 5 czerwca 1992 r., Dz.U. z 2002 r. Nr 184, poz. 1532.

8 Dyrektywa Rady 79/409/EWG Rady z dnia 2 kwietnia 1979 r. o ochronie dziko żyjących ptaków, Dz.U. WE L 103 z 25 kwietnia 1979 r., która zastąpiona została nową Dyrektywą 2009/147/WE Parlamentu Europejskiego i Rady $z$ dnia 30 listopada 2009 r. w sprawie ochrony dzikiego ptactwa.

9 Dyrektywa Rady 92/43/EWG z dnia 21 maja 1992 r. w sprawie ochrony siedlisk przyrodniczych oraz dzikiej fauny i flory, Dz.U. WE L 206 z 22 lipca 1992 r.
} 
oraz ochronie bioróżnorodności. ${ }^{10}$ Aby możliwe było osiągnięcie wymienionych celów w ramach istniejącej wspólnoty europejskiej przyjęta została w 1979 r. tzw. dyrektywa ptasia (zastąpiona w 2009 r. dyrektywą ptasią skonsolidowaną) jako akt prawa ściśle powiązany i rozwijający wizję działań w odniesieniu do ptaków. Natomiast w 1992 r. przyjęta została tzw. dyrektywa siedliskowa, która zobowiązała państwa członkowskie Unii Europejskiej do wprowadzenia podstaw prawnych dla rozwoju sieci obszarów chroniących zagrożone w skali europejskiej gatunki roślin, zwierząt i rodzaje siedlisk przyrodniczych. Wymienione wyżej dyrektywy są podstawą prawną funkcjonowania Europejskiej Sieci Ekologicznej Natura 2000 (dalej jako: „ESEN 2000”). Sieć ta z założenia ma umożliwić realizację spójnej polityki ochrony zasobów przyrodniczych na obszarze Unii Europejskiej. Spójna polityka w tym zakresie to stworzenie obszarów specjalnej ochrony ptaków (dalej jako: „OSO”) oraz specjalnych obszarów ochrony siedlisk (dalej jako: „SOO”). Polska, jak i inne państwa wstępujące do Unii Europejskiej zobowiązały się do wyznaczania obszarów Natura 2000. Zatem należałoby wyjaśnić najważniejsze idee wynikające z wymienionych dyrektyw w stosunku do Sieci Natura 2000.

Dyrektywa ptasia nakłada na państwa członkowskie Unii obowiązek podjęcia działań, które zapewnią trwałą egzystencję dziko żyjącym gatunkom europejskim awifauny (czyli ogółu ptaków zamieszkujących dany obszar, środowisko lub żyjących w określonej epoce geologicznej ${ }^{11}$ ). Z załącznika I do tej dyrektywy wynika obowiązek ochrony w formie OSO 180 gatunków ptaków wymierających bądź zagrożonych wyginięciem, głównie wskutek niekorzystnych zmian zachodzących w typowych dla nich siedliskach. Ma to na celu zapewnienie im przetrwania oraz reprodukcji na obszarze ich występowania (art. 4 ust. 1 i 2 dyrektywy ptasiej).

Druga z nich - dyrektywa siedliskowa - zobowiązuje kraje unijne do ochrony naturalnych typów siedlisk gatunków roślin i zwierząt, jako nadrzędnego działania w celu zachowania populacji w ich naturalnym środowisku. W załączniku I tej dyrektywy określono liczbę siedlisk, w tym siedlisk priorytetowych, których ochrona wymaga wyznaczenia SOO ze względu na ich rzadkość i/lub zagrożenie. Ponadto, w załączniku II zamieszczono gatunki fauny i flory objęte SOO, wśród których są również gatunki priorytetowe. Zgodnie z przepisami dyrektywy siedliskowej każde państwo członkowskie powinno brać udział w tworzeniu Natury 2000 proporcjonalnie do występowania na jego terytorium typów siedlisk przyrodniczych i siedlisk gatunków, wyznaczając tereny stanowiące SOO (art. 4 i 5 dyrektywy siedliskowej).

Zarówno OSO, jak i SOO tworzą sieć Natura 2000. Nazwa tej koncepcji ochrony wynika z pierwotnie planowanej daty zakończenia wyznaczania tej sieci, która miała przypadać na rok 2000. Jak zauważył A. Bołtromiuk, ESEN 2000 nie zastępuje istniejących wcześniej krajowych systemów obszarów chronionych, lecz

\footnotetext{
10 A. Bołtromiuk, M. Kłodziński, Natura 2000 jako czynnik zrównoważonego rozwoju obszarów wiejskich regionu Zielonych Płuc Polski, Warszawa 2011, s. 78.

11 Słownik języka polskiego, tryb dostępu: [http://sjp.pl/awifauna] (data dostępu: 4.05 .2013 r.).
} 
powinna je uzupełniać, dając podstawę do zachowania przyrodniczego dziedzictwa przyrodniczego w skali kontynentu. ${ }^{12}$

Ponadto ESEN 2000 to swego rodzaju system najcenniejszych przyrodniczo obszarów połączonych ze sobą korytarzami ekologicznymi. Jako główny cel sieci podaje się: utrzymanie różnorodności biologicznej zarówno poprzez ochronę i odtwarzanie rzadkich siedlisk i gatunków, ale także przez zachowanie charakterystycznych, powszechnie jeszcze występujących układów przyrodniczych, uznanych za cenne ogólnoeuropejskie dobro publiczne.

\section{Aspekt prawny Natury 2000 w świetle prawa polskiego}

Przepisy unijne stanowiące podstawę dla tworzenia sieci Natura 2000 zostały wprowadzone do polskiego prawodawstwa ustawą z dnia 16 kwietnia $2004 \mathrm{r}$. o ochronie przyrody. ${ }^{13}$ Na podstawie tej ustawy, Natura 2000 stała się najmłodszą prawną formą ochrony przyrody w Polsce. Niewiele osób jednak wie, iż przygotowania do wprowadzenia obszarów „naturowych” w Polsce rozpoczęły się już pod koniec lat 90. XX w. Sporządzono wtedy wstępne analizy zasobów siedlisk i gatunków wymagających ochrony w sieci, a także prowadzono negocjacje odnośnie uzupełnienia przepisów unijnych o siedliska i gatunki wymagające ochrony w Polsce, a nieobecne w krajach starej Unii Europejskiej i w związku z tym nieobjęte ochroną ówczesnego prawa unijnego. ${ }^{14}$

Zgodnie $\mathrm{z}$ art. 5 pkt $2 \mathrm{~b}$ u.o.p. obszar Natura 2000 to obszar specjalnej ochrony ptaków, specjalny obszar ochrony siedlisk lub obszar mający znaczenie dla Wspólnoty, utworzony w celu ochrony populacji dziko występujących ptaków lub siedlisk przyrodniczych lub gatunków będących przedmiotem zainteresowania Wspólnoty. Z ustawy o ochronie przyrody wynika także, iż Natura 2000 obejmuje:

1) obszary specjalnej ochrony ptaków (OSO), czyli obszary wyznaczone, zgodnie z przepisami prawa Unii Europejskiej, do ochrony populacji dziko występujących ptaków jednego lub wielu gatunków, w którego granicach ptaki mają korzystne warunki bytowania w ciągu całego życia, w dowolnym jego okresie albo stadium rozwoju (art. 5 pkt 3 u.o.p.);

2) specjalne obszary ochrony siedlisk (SOO), czyli obszary wyznaczone, zgodnie z przepisami prawa Unii Europejskiej, w celu trwałej ochrony siedlisk przyrodniczych lub populacji zagrożonych wyginięciem gatunków roślin lub zwierząt lub w celu odtworzenia właściwego stanu ochrony siedlisk przyrodniczych lub właściwego stanu ochrony tych gatunków (art. 5 pkt 19 u.o.p.), oraz

A. Bołtromiuk, M. Kłodziński, Natura 2000 jako czynnik zrównoważonego..., op. cit., s. 78.

Dz.U. z 2014 r. poz. 1101, dalej jako: „u.o.p.”.

Oficjalna strona internetowa Generalnej Dyrekcji Ochrony Środowiska, tryb dostępu: [http://natura2000.gdos.gov. $\mathrm{pl} /$ strona/natura-2000-w-polsce] (data dostępu: 4.05.2013 r.). 
3) obszary mające znaczenie dla Wspólnoty, czyli projektowane specjalne obszary ochrony siedlisk, zatwierdzone przez Komisję Europejską w drodze decyzji, które w regionie biogeograficznym, do którego należą, w znaczący sposób przyczyniają się do zachowania lub odtworzenia stanu właściwej ochrony siedliska przyrodniczego lub gatunku będącego przedmiotem zainteresowania Wspólnoty, a także mogą znacząco przyczynić się do spójności sieci obszarów Natura 2000 i zachowania różnorodności biologicznej w obrębie danego regionu biogeograficznego. Natomiast w przypadku gatunków zwierząt występujących na dużych obszarach obszarem mającym znaczenie dla Wspólnoty jest obszar w obrębie naturalnego zasięgu takich gatunków, charakteryzujący się fizycznymi lub biologicznymi czynnikami istotnymi dla ich życia lub rozmnażania (art. 5 pkt 2c u.o.p.).

Pomimo iż Natura 2000 stanowi odrębną formę ochrony przyrody, to w związku z art. 25 ust. 2 u.o.p. wynika, iż może ona obejmować część lub całość obszarów i obiektów podlegających już ochronie w formie parku narodowego, rezerwatu przyrody, parku krajobrazowego, obszaru chronionego krajobrazu, pomnika przyrody, stanowiska dokumentacyjnego, użytku ekologicznego lub zespołu przyrodniczokrajobrazowego. Jak stwierdza A. Kazimierska-Patrzyczna obszar Natura 2000 zostaje objęty wówczas podwójnym reżimem prawnym - właściwym dla danej formy ochrony, istniejącej na tym terenie oraz reżimem wynikającym z ustawy o ochronie przyrody - specjalnie dla obszarów Natura 2000 (art. 33 ust. 1 u.o.p.).$^{15}$ Naturę 2000 od innych form ochrony przyrody różni to, że chroni ona nie całość przyrody, lecz jej część i zawsze ma swój wyodrębniony cel - ochronę ważnych w skali europejskiej siedlisk i gatunków. Dlatego też możliwa jest lokalizacja inwestycji na tych terenach, pod warunkiem, że takie działania nie wpływają w znaczący sposób negatywnie na gatunki i siedliska, ze względu na które został wyodrębniony obszar Natura 2000. Obszarowe formy ochrony przyrody, do których należy Natura 2000 zdaniem A. Habudy wpisują się w definicję obszaru specjalnego, oznaczającego pewien wycinek przestrzeni wyodrębniony ze względu na potrzebę realizacji określonych celów państwowych, realizowanych przez administrację państwową. Na terenie obszaru specjalnego obowiązuje szczególny reżim prawny. ${ }^{16}$ Jak zostało podkreślone $\mathrm{w}$ doktrynie, każdy z obszarów specjalnych ma regulację prawną zmierzającą do zapewnienia realizacji celu, dla którego utworzono rodzaj obszaru specjalnego, zaś w pozostałym zakresie obowiązuje reżim prawny powszechny. ${ }^{17}$ Reżim prawny obszarów Natura 2000 zmierza do tego, aby chronić konkretne siedliska i gatunki, ze względu na których istnienie wyznaczono taką formę ochrony przyrody.

\footnotetext{
15 A. Kaźmierska-Patrzyczna, Obszary Natura 2000 jako instytucja prawnej ochrony różnorodności biologicznej, (w:) M. Górski, Prawo ochrony różnorodności biologicznej, Warszawa 2013, s. 116.

A. Haduba, Obszary Natura 2000 w prawie polskim, Warszawa 2013, s. 28.

J. Boć, E. Samborska-Boć, Obszary specjalne, (w:) Ochrona środowiska, Wrocław 2000, s. 280.
} 
W doktrynie podnosi się stanowisko, że tworzenie nowej formy ochrony przyrody nie było konieczne, bo cele zawarte w dyrektywach: ptasiej i siedliskowej mogły być realizowane na podstawie dotychczasowego katalogu form ochrony przyrody. Żaden z przepisów wymienionych w dyrektywach nie zawiera wyraźnego obowiązku utworzenia przez władze krajowe nowej formy ochrony przyrody, ponieważ mowa tam o utworzeniu spójnej europejskiej sieci ekologicznej. Stąd można mówić, iż Natura 2000 to nazwa sieci specjalnych obszarów ochrony położonych na terenie państw członkowskich UE, a nie nakazana przez ustawodawcę wspólnotowego nowa krajowa forma ochronna. ${ }^{18}$

\section{Natura 2000 a zrównoważony rozwój - czy to możliwe?}

Z jednej strony funkcjonowanie sieci Natura 2000 obwarowane jest regulacjami prawnymi dotyczącymi warunków ochrony OSO i SOO, zaś z drugiej nie zakazuje prowadzenia działalności gospodarczej czy inwestycji na terenach objętych siecią, o ile nie wywierają one wpływu mogącego znacząco oddziaływać na środowisko objęte siecią N2000 (art. 36 u.o.p.). Zatem nasuwa się pytanie, skąd wynika wrogie nastawienie wobec ,obszarów naturowych”. Powstanie sieci Natura 2000 w Polsce budziło wiele emocji. Wobec tej koncepcji wykształciły się dwa stanowiska: pierwsze skupiające zwolenników, drugie - przeciwników. Poniżej przedstawię najczęściej przytaczane argumenty przez te grupy.

Argumenty ,za” tworzeniem obszarów Natura 2000 przedstawił m.in. dr Piotr Otawski. Jego zdaniem, program Natura 2000 ma ważny wpływ na planowanie rozwoju lokalnego w gminach oraz w procesie inwestycyjnym. Społeczeństwo niekiedy błędnie postrzega konsekwencje tworzenia takich obszarów, co jest podstawą do blokowania wszelkich inwestycji. Jednak dane statystyczne wskazują, że 95\% decyzji wydawanych przez Regionalne Dyrekcje Ochrony Środowiska zezwala na realizacje inwestycji na obszarach „naturowych” lub w ich otoczeniu. Współcześnie władze wielu samorządów z faktu posiadania obszarów Natura 2000 potrafią uczynić atut, np. poprzez realizacje strategii produktu lokalnego, turystycznego czy produkcji żywności ekologicznej. ${ }^{19} \mathrm{Z}$ obecności obszaru Natura 2000 można czerpać wiele korzyści. Przede wszystkim wzmaga to promocję regionu. Przykładem na potwierdzenie tego argumentu jest Dolina Biebrzy. Dzięki obszarom Natura 2000 w regionie tym obserwuje się wzrost liczby turystów krajowych, jak i zagranicznych. Utworzenie obszaru Natura 2000 niesie możliwości rozwoju szeroko rozumianej turystyki, począwszy od gospodarstw agroturystycznych po wzrost znaczenia produktów eko-

18 J. Jerzmański, Nowa ustawa o ochronie przyrody, „Zeszyty Komunalne” 2005, nr 1, s. 42 oraz A. Haduba, Status
obszarów Natura 2000 w prawie polskim i unijnym, (w:) A. Bołtromiuk, M. Kołodziejski, Natura 2000 jako czynnik
zrównoważonego rozwoju obszarów wiejskich regionu Zielonych Płuc Polski, Warszawa 2011, s. 113-114.
Wywiad z dr. Piotrem Otawskim - Zastępcą Generalnego Dyrektora Ochrony Środowiska (8.12.2011 r.), do-
stęp:http://www.forbes.pl/artykuly/sekcje/wydarzenia/natura-2000--fakty-i-mity,22288,1 (data dostępu: 5.05.2013 r.). 
logicznych i regionalnych. Konsekwencją tego jest napływ nowych inwestycji, które dodatkowo napędzają mechanizmy ożywienia i rozwoju regionalnego. Kolejną korzyścią wynikającą z ustanowienia obszaru Natura 2000 są dodatkowe profity finansowe ze specjalnych programów rolnośrodowiskowych skierowane do podmiotów prowadzących gospodarstwa rolne. Zauważono także, iż stworzenie obszaru „naturowego" spowodowało wzmocnienie tożsamości regionalnej i poczucia odpowiedzialności za zamieszkiwane tereny, a w konsekwencji zmieniło niekorzystne często tendencje migracyjne polskich kadr. ${ }^{20}$ Ponadto, Natura 2000 jest formą ochrony przyjazną człowiekowi. Na terenach tych nie obowiązują zakazy skierowane do ludzi, np. ,zakaz wstępu do lasu”. Preferuje się jednak wykorzystywanie metod gospodarki tradycyjnej, przykładowo: ochrona łąk poprzez wypas czy ich wykaszanie. ${ }^{21}$

Argumentem przytaczanym przez przeciwników jest niekorzystny wpływ obszaru Natura 2000 na sytuację ekonomiczną regionu i jego mieszkańców. Przykładowo: budowa ośrodka wypoczynkowego w centrum siedliska z sieci Natura 2000 nie może być zrealizowana, gdy negatywnie wpływa na gatunki i siedliska. ${ }^{22}$ W związku z tym chroniona jest bioróżnorodność, jednak kosztem nowych miejsc pracy, potencjalnych zysków z turystyki. Przeciwnicy twierdzą także, iż Natura 2000 nie zawsze jest impulsem rozwoju gospodarczego. W związku z tym, jeżeli zostanie wykazany negatywny wpływ przedsięwzięcia na przedmiot ochrony objęty siecią Natura 2000, to w przypadku braku rozwiązań alternatywnych oraz nadrzędnego interesu publicznego przedsięwzięcia takiego nie można zrealizować. Niewątpliwie ważnym argumentem przeciwko sieci Natura 2000 jest to, że na rekompensaty dla tych, którzy ponoszą dodatkowe koszty i tracą potencjalne korzyści z tytułu nowych ograniczeń oraz na tworzenie i utrzymanie obszarów „naturowych” przeznacza się niewielkie środki. Do tego dochodzą obawy, iż wprowadzenie nowych ograniczeń gospodarczych, np. w postaci konieczności sporządzania oceny oddziaływania planowanych inwestycji na środowisko może spowolnić rozwój tych terenów oraz wydłużyć czas realizacji danych przedsięwzięć. ${ }^{23}$

Jak zauważono w piśmiennictwie, zachowanie równowagi między potrzebami ochrony środowiska a rozwojem gospodarczym jest możliwe, aczkolwiek wymaga dialogu i wzajemnego zrozumienia racji zgłaszanych interesów społecznych, jak i prywatnych. Ponadto, w Polsce dominuje pogląd, iż ochrona przyrody generalnie przeszkadza w rozwoju. Myśl ta została silnie ugruntowana na szczeblu samorządowym i wynikała z braku wiedzy na temat funkcjonowania systemu Natura 2000, jej wad i zalet oraz z braku kompromisu pomiędzy władzami samorządowymi a pod-

20 Dostęp: http://www.portfel.pl/pdf/art847: (data dostępu: 5.05 .2013 r.).

21 Dostęp: http://www.azr.gig.eu/sites/default/files/AZR_prezentacja\%20_siec\%20NATURA_LT.pdf (data dostępu: 7.05.2013 r.).

22 Ibidem.

23 A. Bołtromiuk, Zrównoważony rozwój obszarów przyrodniczo cennych. Gospodarcze i społeczne aspekty funkcjonowania sieci Natura 2000 w parkach narodowych, Białystok 2011, s. 162-163. 
miotami zaangażowanymi w wytyczanie granic sieci, a także braku kadry wykwalifikowanej w znajomości sieci N2000. ${ }^{24}$

Wydaje się, iż można znaleźć kompromis pomiędzy rozwojem gospodarczym a ochroną przyrody na obszarach Natura 2000 . Warto zauważyć, że ta forma przyrody dopuszcza pewne działania człowieka na terenach objętych siecią. Zgodnie $\mathrm{z}$ art. 36 ustawy o ochronie przyrody, działalność gospodarcza, rolnicza, leśna, łowiecka, rybacka oraz turystyczna na obszarach „naturowych” jest dopuszczalna pod pewnymi warunkami. Mianowicie, planowana inwestycja bądź działalność nie powinna wywierać negatywnego wpływu na siedliska przyrodnicze oraz gatunki zwierząt i roślin, do ochrony których została utworzona ESEN 2000. Jak podaje piśmiennictwo, Natura 2000 nie ma cech tradycyjnych form ochrony przyrody (np. rezerwat), z których wynika, iż działalność ludzka jest zabroniona. Podkreśla się, że priorytetem ESEN 2000 jest zapewnienie równowagi między rozwojem gospodarczym a ochroną i poszanowaniem różnorodności biologicznej. ${ }^{25} \mathrm{Co}$ więcej, dopuszcza się nawet inwestycje negatywnie oddziaływujące na przyrodę, w sytuacji gdy istnieje nadrzędny interes publiczny i brak alternatywnego rozwiązania (art. 34 u.o.p.). W takim jednak przypadku należy dokonać kompensacji przyrodniczej, która zapewni właściwe funkcjonowanie sieci Natura 2000. Jeśli istnieje podejrzenie, że dana inwestycja może mieć znaczący negatywny wpływ na gatunki i siedliska objęte ochroną w ramach sieci, wtedy obowiązkowe jest postępowanie w sprawie oceny oddziaływania na środowisko według zasad określonych w ustawie prawo ochrony środowiska.

\section{Zrównoważony rozwój a ochrona środowiska}

Istnieje wiele definicji zrównoważonego rozwoju. Jedna z nich podaje, iż zrównoważony rozwój to sposób gospodarowania uwzględniający zaspokojenie potrzeb obecnych, jak i przyszłych pokoleń, łączący się z racjonalnym wykorzystaniem środowiska przyrodniczego, zapewniający poprawę jakości życia i stanu samego środowiska. ${ }^{26}$ Można tutaj zauważyć podobieństwo do definicji ustawowej, a nawet stwierdzić, że zakres obu jest identyczny. W piśmiennictwie zauważa się trzy wymiary zrównoważonego rozwoju ${ }^{27}$ :

- ekonomiczny (rozwój gospodarczy, produkcja dóbr i usług zaspokajających potrzeby ludzkie);

- społeczny (m.in. zapewnienie odpowiedniego poziomu dobrobytu, zaspokojenie potrzeb materialnych i niematerialnych);

24 A. Bołtromiuk, Zrównoważony rozwój obszarów przyrodniczo..., op. cit., s. 162.

25 Dostęp: http://www.natura2000.efort.pl/pliki/2012/dzialalnosc_gosp_natura2000.pdf(data dostępu: 7.05.2013 r.).

26 B. Piontek, Koncepcja zrównoważonego i trwałego rozwoju Polski, Warszawa 2002, s. 51.

27 T. Poskrobko, Zrównoważony rozwój obszarów przyrodniczo cennych. Planistyczne i implementacyjne aspekty rozwoju obszarów przyrodniczo cennych, Białystok 2011, s.149. 
- ekologiczny (ochrona środowiska i zachowanie równowagi biologicznej, jego produktywności i bioróżnorodności).

Dla formy ochrony przyrody, jaką jest Natura 2000 kluczowe znaczenie będzie miał wymiar ekologiczny. W związku z tym zrównoważone użytkowanie terenów chronionych powinno być tak prowadzone, aby:

- uniknąć trwałego zniekształcenia lub zniszczenia cennych przyrodniczo elementów i ekosystemów, w tym różnorodności biologicznej;

- doprowadzić do odtworzenia elementów wcześniej zdegradowanych lub utraconych.

Z powyższego wynika to, że wszelkie działania mające na celu ochronę cennych przyrodniczo obszarów nie powinny prowadzić do pogorszenia jakości życia osób i społeczności zamieszkujących te tereny. ${ }^{28}$

Inne źródła podają, iż w odniesieniu do sieci Natura 2000 zrównoważony rozwój powinien być rozumiany jako dążenie do równego i trwałego dostępu społeczności całego kraju, poszczególnych regionów oraz społeczności lokalnych do wartościowego, czystego oraz bezpiecznego środowiska. Co więcej, zrównoważony rozwój wyznaczany jest przede wszystkim przez:

- dostosowanie skali ingerencji w środowisko do jego naturalnej odporności na zanieczyszczenia i zakłócenia;

- zachowanie zdolności do odtwarzania zasobów naturalnych lub zastępowanie ich substytutami, przy wyraźnej preferencji wykorzystania zasobów odnawialnych;

- zachowanie różnorodności biologicznej i krajobrazowej;

- zapewnienie bezpieczeństwa ekologicznego. ${ }^{29}$

W każdej z przytaczanych wyżej definicji zauważalne jest podobieństwo do definicji legalnej z p.o.ś. We wszystkich została wyrażona idea ochrony środowiska dopuszczająca rozwój na obszarach objętych siecią Natura 2000, ale z poszanowaniem fauny i flory tam występującej.

\section{Podsumowanie}

Rozpatrując funkcjonowanie sieci Natura 2000 w aspekcie zrównoważonego rozwoju można dojść do wniosku, iż idea ochrony przyrody właśnie w tej formie ma kluczowe znaczenie dla zachowania bioróżnorodności kontynentu europejskiego

Ibidem, s. 149.

Oficjalna strona internetowa „Natura 2000 a turystyka”, dostęp: http://natura2000.org.pl/e-szkolenia/e9-zrownowazony-rozwoj-obszarow-natura-2000-2/zrownowazony_rozwoj (data dostępu: 5.05.2013 r.). 
(innymi słowy, jest to zachowanie dziedzictwa przyrodniczego Europy, czyli cennych siedlisk przyrodniczych i gatunków). Warto też podkreślić, iż ESEN 2000 nie zastępuje istniejących wcześniej krajowych systemów obszarów chronionych, lecz je uzupełnia.

Działania podejmowane w ramach sieci Natura 2000 są realizacją zasady zrównoważonego rozwoju, ponieważ sprzyjają rozwojowi tych terenów, jednocześnie nie powodując negatywnego wpływu na środowisko. Dlatego też gospodarowanie w sąsiedztwie obszarów chronionych (w tym obszarów Natura 2000) jest możliwe, ale pod warunkiem uwzględniania wrażliwości chronionych na tych obszarach gatunków i siedlisk oraz unikania istotnych dla nich zagrożeń. W Polsce dostępność terenów chronionych dla trwałego zagospodarowywania jest ograniczona w niewielkim stopniu. Dotyczy to także dostępności komercyjnej, a więc przynoszącej korzyści materialne inwestorom i organizatorom.

Ponadto, posiadanie na swoim terenie obszaru przyrodniczego uznanego za cenny w skali całej Unii Europejskiej jest postrzegane jako miejsce, gdzie występuje wysoka jakość życia. Ochrona obszarów cennych przyrodniczo zawsze musi się wiązać z ograniczeniem rozwoju gospodarczego na obszarach „naturowych”. Dlatego też z uwagi na duży zasięg przestrzenny sieci na jej obszarach lub w bezpośrednim sąsiedztwie zlokalizowanych jest wiele podmiotów wykorzystujących obszary Natura 2000 do innych celów niż ochrona środowiska, np. rolnictwa, leśnictwa, rybołówstwa, turystyki czy rekreacji.

Nadal w społeczeństwie istnieje negatywne nastawienie do sieci Natura 2000, które moim zdaniem wynika z braku wiedzy na ten temat. Dlatego też instytucje różnych szczebli zaangażowały się w tworzenie różnego rodzaju szkoleń z zakresu funkcjonowania obszarów ,naturowych” skierowanych do określonych podmiotów. ${ }^{30}$

Jak podają dane Generalnej Dyrekcji Ochrony Środowiska, obecnie w Polsce sieć Natura 2000 zajmuje prawie 1/5 powierzchni lądowej kraju. W jej skład wchodzi: 845 obszarów specjalnej ochrony siedlisk oraz 145 obszarów specjalnej ochrony ptaków. Zauważa się, że nadal nie wszystkie gatunki i siedliska są wystarczająco chronione i wskazano konieczność uzupełnień, których skala jest już jednak niewielka w porównaniu do początkowych braków. 


\section{NATURA 2000 AS AN ACTION FOR SUSTAINABLE DEVELOPMENT}

Nature protection in the form of the Natura 2000 network has undoubtedly had an influenced on sustainable development. The author presents some of the problems that can arise when considered in the context of European and Polish regulations, having regard to the functioning of the Natura 2000 sites. Also presented are the advantages and disadvantages of this form of conservation. The content of this paper seeks to answer the question of whether a 'golden' medium can be found between the Natura 2000 form of nature conservation and economic development of the sites covered. This work aims to show that it is possible to do business in Natura 2000 areas consistent with the principle of sustainable development.

Keywords: sustainable development, special areas of conservation habitats, special bird protection areas, advantages and disadvantages of the Natura 2000 network 